\title{
Jack Hills zircons record the appearance of peraluminous melts on the early Earth
}

\author{
M.R. ACKERSON ${ }^{1 *}$, D. TRAIL ${ }^{2}$ \\ ${ }^{1}$ Dept. of Mineral Sciences, Smithsonian National Museum of \\ Natural History, Washington, DC 20013 \\ (*correspondence: ackersonm@si.edu) \\ ${ }^{2}$ Dept. of Earth and Envi. Sci, University of Rochester, \\ Rochester, NY 14627
}

Detrital zircons from the Jack Hills metaconglomerate record almost all of Earth's first $\sim 1.4$ billion years. Although a significant amount of research into these minerals has focused on the Hadean-aged zircon population, the full suite of zircons from these rocks can provide a glimpse into secular changes in the crust from 4.4 to 3 billion years ago (Ga). During this time interval the Earth experienced significant cooling, the formation of liquid water oceans, and the stabilization of continental crust. One outstanding problem on the early Earth is the how tectonics evolved over time (e.g., a potential stagnant lid to a mobile lid to modern-style tectonics). In part, this problem can be addressed by looking at the detrital Jack Hills zircons, the majority of which are derived from magmatic protoliths [1].

One potentially useful metric for elucidating the magmatic history of Jack Hills zircons is their aluminum content. In modern granitic systems, $\mathrm{Al}$ content has been shown to depend on melt peraluminosity (ASI $>1$ ). This is particularly striking in the Lachlan Fold Belt, where zircons from S-type granitoids (which are derived in part from melting of pelitic sources) contain unambiguously higher $\mathrm{Al}$ concentrations than neighboring I-type granitoids [2]. Experimental studies confirm an increase in $\mathrm{Al}$ content of zircons with increasing melt ASI [3]. In this study, we use Al content of zircons in the Jack Hills to monitor the onset of peraluminous magmas. Our results demonstrate that around $\sim 3.6 \mathrm{Ga}$ there is a significant shift in the average $\mathrm{Al}$ content in the zircons, likely indicating a rise in peraluminous melts at this time. This rise in peraluminous melts could be due to the several petrologic/tectonic processes, including deep melting and fractionation of igneous protoliths or melting of pelitic sediments. Future research will help to determine which of these processes is the most likely cause of the rise of peraluminous melts, and therefore what these melts can tell us about geodynamics on the early Earth.

[1] Burnham \& Berry (2017) Nat. Geosci 10, 457-461. [2] Trail et al. (2017) Geochem. Geophys. Geosystems 18, 15801593. [3] Wang \& Trail (2019) Chem. Geol. 511, 71-80. 